\title{
PERBAIKAN MANAJEMEN PEMELIHARAAN DALAM MENUNJANG USAHA TERNAK BABI SKALA RUMAH TANGGA, DESA PENFUI TIMUR, KABUPATEN KUPANG
}

\author{
Cynthia Gaina *, Nemay Anggadewi Ndaong *, Nancy Foeh* \\ *Fakultas Kedokteran Hewan, Universitas Nusa Cendana \\ email: cynthia.gaina@staf.undana.ac.id
}

\begin{abstract}
ABSTRAK
Kegiatan pengabdian ini bertujuan mengoptimalisasi pemberdayaan masyarakat peternak Matani Helituan yang berada disekitar kampus Undana melalui perbaikan manajemen pemeliharaan ternak babi skala rumah tangga. Kegiatan ini meliputi pembangunan kandang babi yang sehat, peninjauan pemeliharaan induk-anak, pengolahan pakan babi fermentasi dan pelayanan kesehatan ternak babi di kelompok ternak Matani Helituan I dan Matani Helituan II, desa Penfui Timur, Kecamatan Kupang Tengah, Kabupaten Kupang, NTT. Beberapa kegiatan yang telah dilakukan berlandaskan pada aspek kesejahteraan hewan. Kegiatan yang dilakukan meliputi 1) pertemuan dengan anggota kelompok peternak dari dua mitra yang juga dihadiri oleh aparatur pemerintah desa dalam rangka mensosialisasikan rencana kegiatan pengabdian yang telah disetujui oleh DIKTI; 2) pembuatan kartu kontrol kesehatan babi (KKSB) dan pelayanan kesehatan ternak babi; 3) pembangunan kandang babi sehat dan 4) pelatihan pembuatan pakan babi fermentasi dengan memanfaatkan bahan lokal. Secara umum kegiatan IbM dinilai berjalan dengan baik. Mitra kegiatan sangat antusias dalam mengikuti pelatihan pembuatan pakan fermentasi, pemilihan bibit unggul maupun dalam hal kerjasama membangun kandang babi sehat. Luaran yang dihasilkan antara lain publikasi kegiatan, peningkatan pemahaman mitra akan pentingnya kesehatan ternak babi, pendataan (recording) pemeliharaan ternak baik yang baik dan terarah serta pemanfaatan bahan lokal untuk pakan fermentasi babi yang semuanya berlandaskan aspek kesejahteraan hewan.
\end{abstract}

Kata Kunci: Babi, Matani Helituan, Kandang, Pakan Fermentasi, Kartu Sehat 


\section{PENDAHULUAN}

Usaha ternak babi merupakan salah satu jenis usaha bidang peternakan yang disukai baik oleh masyarakat peternak skala besar maupun skala kecil. Beberapa alasan yang menjadikannya sebagai usaha yang menjanjikan bagi peternak skala kecil atau skala rumah tangga, khususnya bagi peternak babi Matani Helituan, desa Penfui Timur, Kabupaten Kupang adalah 1) pasar ternak babi yang menjanjikan di NTT, 2) tidak memerlukan lahan yang luas, 3) pakan bersumber dari limbah rumah tangga dan pakan komersial yang sudah banyak tersedia dan 4) statusnya sebagai hewan socio-budaya menjadikan babi menjadi ternak unggulan masyarakat NTT, khususnya peternak desa Matani. Akan tetapi, hal-hal tersebut perlu didukung dengan berbagai strategi terutama bagi wilayah kabupaten Kupang yang makin padat dengan beranekaragam pemeluk keyakinan.

Usaha ternak babi yang dilakukan oleh masyarakat peternakan di desa Penfui Timur, Kabupaten Kupang selama ini masih bersifat seadanya baik dari aspek perkandangan, pakan, maupun sanitasi dan kesehatannya. Untuk aspek pemeliharaan dilihat dari sistem perkadangannya sangat bervariasi yaitu dari yang masih bersifat ekstensif atau melepaskan hewan mencari makan sendiri dan tanpa kandang atau diikat pada pepohonan dekat rumah sampai dengan yang sudah memiliki kesadaran untuk membangun kandang tradisional bahkan semi permanen. Selain itu, permasalahan lain timbul akibat pembangunan kandang seadanya tanpa memperhatikan aspek hiegene dan sanitasi dimulai dari tempat pakan dan minum, lantai kandang yang masih beralaskan tanah dan jarang dibersihkan sehingga menjadi sarana penyebaran penyakit melalui lalat dan tidak adanya tempat pembuangan limbah yang tertutup. Beberapa peternak sudah memiliki tempat pembuangan limbah, namun lubang limbah dibiarkan terbuka, sehingga dapat menjadi saran penyebaran penyakit baik bagi manusia maupun ternak.

Dari sisi lain, pakan dan kesehatan ternak juga merupakan masalah yang kurang mendapat perhatian sehingga turut memperburuk kondisi genetik akibat sistem perkawinan yang tidak terkontrol. Harga pakan komersil yang semakin mahal menjadi salah satu tantangan pemeliharaan bagi peternak babi desa Matani, sehingga diperlukan upaya untuk menyediakan pakan alternatif dari bahan-bahan lokal bagi ternak babi yang dipelihara tanpa mengurangi kebutuhan nutrisi ternak babi (Lailogo dkk, 2014). Manajemen kesehatan atau kontrol terhadap penyakit merupakan salah satu faktor penentu keberhasilan usaha peternakan babi. Ternak babi cukup peka terhadap beberapa penyakit, seperti diare, kecacingan dan hog 
cholera. Adanya endoparasit pada babi dapat menyebabkan penurunan nafsu makan yang akan menghambat pertumbuhan ternak. Gejala yang tampak jika babi terinfeksi cacing adalah kelemahan tubuh, kurus, bulu rontok, buncit, anemia dan diare.

Berdasarkan analisa situasi diatas, kekhawatiran yang paling utama dari masalah-masalah peternakan yang umum terjadi pada peternakan Matani Helituan adalah usaha ternak babi menjadi kurang berkembang. Oleh karena itu, program pengabdian ini diarahkan untuk membantu para peternak desa Matani dengan cara melatih dan mendampingi para peternak babi untuk mengembangkan usaha babi skala rumah tangga yang meliputi pembuatan kartu kontrol sehat, pembangunan kandang yang sehat, pembuatan pakan fermentasi sebagai alternatif pakan babi dan pelayanan kesehatan ternak babi dengan tetap memperhatikan aspek kesejahteraan hewan. Menurut Korte et al (2007), terdapat 5 konsep dari aspek kesejahteraan hewan dari World Society for Protection of Animals (WSPA) yang dikenal dengan nama "Five (5) Freedom of Animal Welfare" yang juga didukung oleh UU. No. 18 tahun 2009 pasal 66-67 tentang Kesejahteraan Hewan. Lima aspek/ prinsip kesejahteraan hewan tersebut adalah 1) bebas dari rasa lapar dan haus (freedom from hunger and thirst), 2) bebas dari rasa panas dan tidak nyaman (freedom from discomfort), 3) bebas dari luka, penyakit dan sakit (freedom from pain, injury and disease), 4) bebas dari rasa takut dan penderitaan (freedom from fear and distress) dan 5) bebas mengekspresikan perilaku normal dan alami (freedom to express normal behaviour). Aspek-aspek inilah yang menjadi dasar dalam pengabdian berbasis pemberdayaan kelompok ternak babi desa Matani, yaitu dengan mengutamakan kesejahteraan hewan ternak yang akan digunakan bagi masyarakat peternak untuk meningkatkan populasi babi melalui pengeloaan perkembangbiakan ternak babi, perkandangan, pakan dan kesehatan dengan memperhatikan ke-5 aspek kesejahteraan hewan ternak tersebut.

Pelaksanaan IbM ini merupakan salah satu upaya pemberdayaan terhadap kelompok masyarakat peternak babi skala rumah tangga di desa Matani yang bertujuan untuk memberikan ilmu pengetahuan serta keterampilan dalam beberapa hal yaitu pendataan rutin kesehatan ternak babi, pembuatan kandang percontohan yang sehat, pembuatan pembuatan pakan fermentasi sebagai alternatif bagi ternak babi, dan pelayanan kesehatan yang kesemuanya harus memperhatikan ke-5 aspek kesejahteraan hewan tersebut. 


\section{MASALAH}

Secara umum, usaha peternakan babi pada kelompok ternak Matani Helituan sangat bervariasi. Beberapa latar belakang masalah yang dihadapi oleh peternak Helituan adalah:

1. Beberapa peternak masih mengangap beternak babi sebagai usaha sampingan yang bersifat tradisional yang ditandai dengan sistem perkandangan, pola pemberian pakan, dan reproduksi yang seadanya.

2. Dari sisi pencatatan atau recording status kesehatan juga tidak terlalu diperhatikan oleh para peternak desa Matani. Tidak adanya recording yang jelas tentang waktu perkawinan, beranak, pemberian obat cacing atau terapi yang diberikan apabila hewan tersebut sakit akan sangat berdampak pada penurunan produktivitas ternak babi. Bagi kebanyakan peternak skala kecil atau rumah tangga, permasalahan ini merupakan masalah sederhana, namun permasalahan manajemen pemeliharaan terutama manajemen reproduksi merupakan permasalahan penting dan utama dalam menentukan keberhasilan usaha peternakan babi. Recording atau pencatatan merupakan faktor penting untuk mengetahui kinerja reproduksi dari setiap individu ternak babi. Sebagai contoh dalam aspek reproduksi, dengan adanya recording maka akan sangat memudahkan evaluasi terhadap manajemen reproduksi yang sudah diterapkan.

3. Ditinjau dari aspek kesehatan hewan, meningkatnya jumlah kematian ternak babi akibat beberapa penyakit pada babi, seperti diare, kecacingan dan hog cholera. Adanya endoparasit pada babi dapat menyebabkan penurunan nafsu makan yang akan menghambat pertumbuhan ternak. Penyakit Hog cholera adalah penyakit mematikan pada babi yang sering disebabkan oleh ketidaktahuan masyarakat peternak akan pentingnya pencegahan penyebaran atau penularan penyakit pada ternak babi. Masyarakat peternak Matani tidak memiliki pengetahuan akan pentingnya pemberian vaksinasi yang wajib bagi ternak babi dimulai dari umur enam minggu untuk mencegah penyebaran penyakit Hog Cholera. Kurangnya pengetahuan ini dapat menyebabkan peningkatan akan kematian ternak babi dari tahun ke tahun yang berdampak pada kerugian ekonomi bagi peternak skala kecil ini. 


\section{METODE PELAKSANAAN}

Kegiatan pengabdian kepada masyarakat ini melibatkan kelompok peternak babi Matani Helituan I dan kelompok peternak babi Matani Helituan II. Untuk mengatasi masalah yang dihadapi peternak babi di kelompok ternak desa Matani, maka ada beberapa hal yang akan dilakukan oleh tim pelaksana sebagai berikut:

1. Pertemuan dengan kelompok ternak.

2. Pembuatan kartu kontrol kesehatan babi (KKSB) dan pelayanan kesehatan ternak

3. Penyuluhan tentang kesehatan dan manajemen pemeliharaan ternak babi secara umum dan manajemen reproduksinya

4. Pembuatan kandang babi percontohan yang sehat

5. Pembuatan pakan fermentasi sebagai alternatif pakan babi dengan memanfaatkan komposisi bahan-bahan lokal, seperti dedak padi, batang pisang dan batang nira lontar atau putak.

Dalam kegiatan pengabdian ini terjalin hubungan timbal balik antara pengusul dan mitra berupa partisipasi dari anggota peternak lain yang merupakan sumber daya manusia yang potensial untuk diberdayakan bagi usaha ternak babi skala rumah tangga, tersedianya sarana sosialisasi/ penyuluhan di rumah ketua kelompok, tersedianya beberapa bantuan bahan lokal yang dapat dimanfaatkan sebagai bahan pembuat pakan alternatif dan tersedianya lokasi bagi pembangunan kandang babi sehat. Dengan demikian, kelompok peternak ini dapat menjadi sarana edukasi lapangan bagi mahasiswa Fakultas Kedokteran Hewan Undana.

\section{Teknik Pengumpulan Data}

Pengumpulan data dilakukan dengan cara survei dan observasi langsung di lokasi kegiatan.

\section{Teknik Analisis Data}

Analisis data dilakukan dengan mengolah data hasil survei dan observasi kegiatan di lokasi pengabdian dan didiskusikan oleh Tim Pelaksana

\section{Lokasi, Waktu, dan Durasi Kegiatan}

Lokasi kegiatan pengabdian ini dilaksanakan di kelompok peternak Matani Helituan, desa Penfui Timur, Kabupaten Kupang. Waktu kegiatan dimulai pada bulan Maret 2017. Kegiatan ini dilakukan dalam kurun waktu 7 bulan. 


\section{HASIL YANG DICAPAI}

Kegiatan pembibitan ternak babi yang dilakukan di Kelompok ternak Matani Helituan I dan Matani Helituan II ini secara umum dapat dilaksanakan dengan baik. Hampir sebagian besar target dan luaran dapat dicapai di dalam kegiatan yang dilakukan. Namun demikian terdapat juga kendala teknis dan sosial yang ditemui selama pelaksanaan kegiatan ini. Berikut adalah tahapan kegiatan dan hasil yang dicapai selama pelaksanaannya.

\section{Tahap 1. Pertemuan dengan Mitra Binaan}

Dalam merealisasikan target dan luaran kegiatan ini Tim melakukan pertemuan dengan para anggota dari kedua kelompok peternak yang juga dihadiri oleh perangkat desa. Pertemuan awal dilakukan untuk mensosialisasikan rencana kegiatan pengabdian yang telah disetujui oleh DIKTI (Direktorat Pendidikan Tinggi). Pertemuan ini juga dilakukan untuk merencanakan jadwal pertemuan dan kerja yang akan dilakukan selanjutnya. Anggota kelompok terlihat sangat antusias dalam merealisasikan kegiatan yang sebelumnya telah didiskusikan untuk diusulkan. Setelah itu, diadakan lagi pertemuan yang kedua dengan kedua kelompok peternak membicarakan pekerjaan teknis persiapan lokasi dan pembangunan kandang, pelatihan pembuatan pakan babi fermentasi, pembuatan kartu sehat dan pelayanan kesehatan ternak babi.
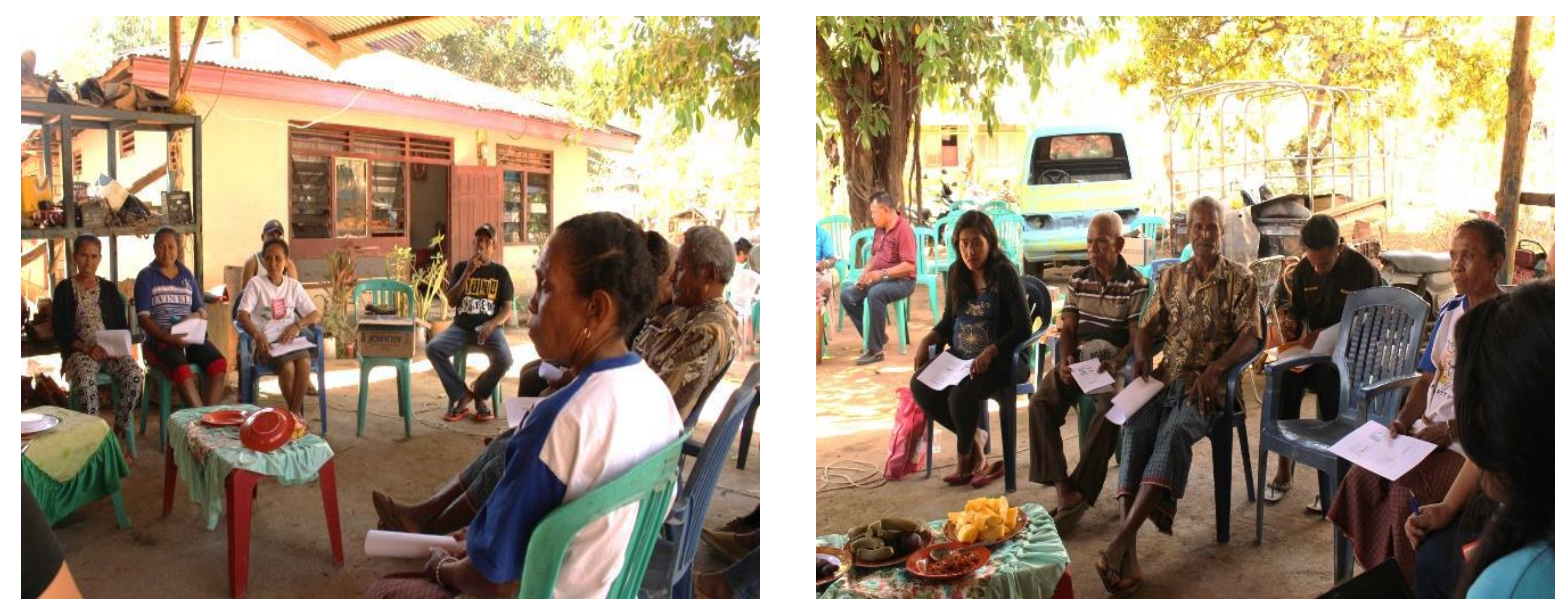


\section{Tahap 2. Pembuatan Kartu Kontrol dan Pelayanan Kesehatan Ternak Babi}

Pembuatan kartu kontrol kesehatan ternak babi bertujuan untuk memudahkan pengontrolan kesehatan ternak babi yang dipelihara oleh kelompok peternak Matani Helituan I dan II di desa Penfui Timur. Adanya kartu kontrol ternak babi ini tidak hanya berguna bagi peternak tapi juga bagi petugas kesehatan hewan dalam memeriksa status kesehatan ternak sehingga akan meningkatkan kesejahteraan bagi peternak. Pencatatan atau recording status kesehatan merupakan aspek yang penting mengetahui kinerja reproduksi dari setiap individu ternak babi yang dipelihara pada peternakan babi Matani Helituan. Sebagai contoh, dengan adanya recording maka akan sangat memudahkan evaluasi terhadap manajemen reproduksi yang sudah diterapkan. Selanjutnya adalah kegiatan pelayanan kesehatan ternak babi berbasis masyarakat untuk membantu peternak skala kecil atau skala rumah tangga. Kegiatan ini dimulai dengan kegiatan penyuluhan tentang pentinganya kesehatan ternak yang berlandaskan pada 5 aspek kesejahteraan hewan dan diikuti dengan pemberian obat cacing dan vitamin bagi ternak babi. Pelayanan kesehatan ternak diharapkan dapat meningkatkan kesadaran masyarakat peternak Matani dalam memelihara dan menghasilkan ternak babi yang sehat dan berkualitas serta bebas dari penyakit.
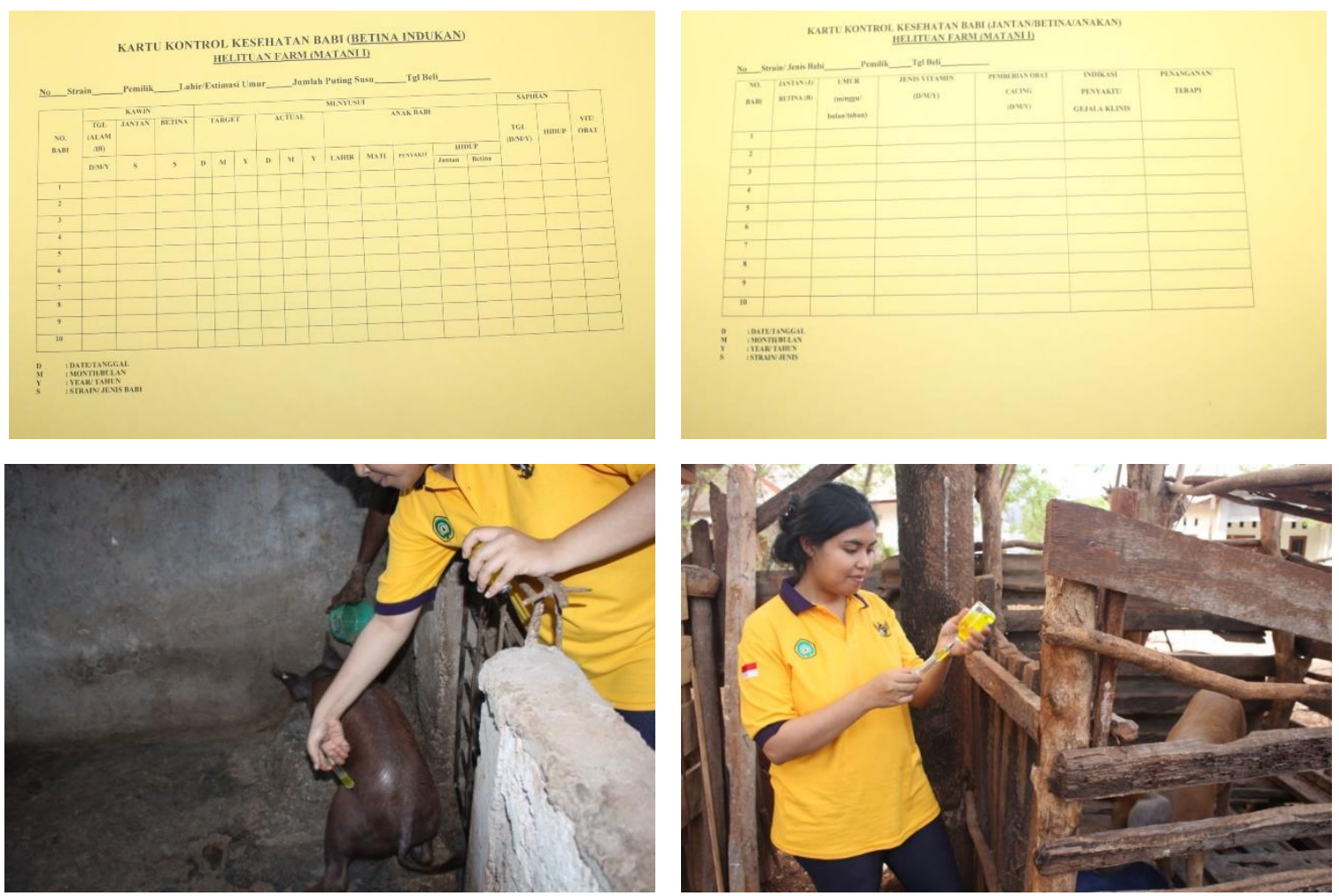


\section{Tahap 3. Pembuatan Kandang Babi Sehat}

Salah satu aspek penting dalam pengabdian ini adalah mensosialisasikan keharusan pembuatan kandang babi sehat ramah lingkungan yang diaktualisasikan dengan pembangunan kandang bagi beberapa peternak Matani Helituan. Untuk mendukung peningkatan produktivitasnya, ternak babi perlu mendapatkan tempat berteduh yang melindungi babi dari gangguan luar yang merugikan, seperti panas, hujan atapun hewan penggangu. Bangunan kandang yang baik harus dapat memberikan keamanan dan kenyaman bagi ternak dan harus dirancang agar tak menimbulkan polusi bagi lingkungan sekitarnya. Bangunan kandang babi yang baik adalah kandang yang cukup mendapatkan penyinaran matahari, ventilasi yang baik, sistem penyaluran kotoran yang baik dengan lantai yang kering dan bersih serta dibuat dari bahan yang murah, berdaya tahan lama dan efisien serta berguna dalam mempertahankan suhu di dalam kandang. Dalam pelaksanaan pengabdian ini, pembangunan kandang dilakukan sesuai dengan kesepakatan bersama mitra peternak dengan pembangunan kandang tipe lantai panggung dan tipe lantai beton. Lantai panggung adalah lantai dengan celah yang dapat membuang atau meneruskan air dan cairan lainnya yang berada di lantai kandang ke bagian bawah kandang. Dengan demikian, lantai panggung dapat menjaga kekeringan lantai kandang dan secara tidak langsung dapat mempertahankan suhu lingkungan sedangkan lantai beton tidak dapat menyerap air tetapi berkontribusi terhadap penurunan suhu lingkungan (Ariana, 2011). Beberapa peternak Matani Helituan memilih lantai panggung karena dinilai lebih ramah lingkungan dengan tidak menimbulkan bau dan lebih efisien dibandingkan dengan lantai beton.
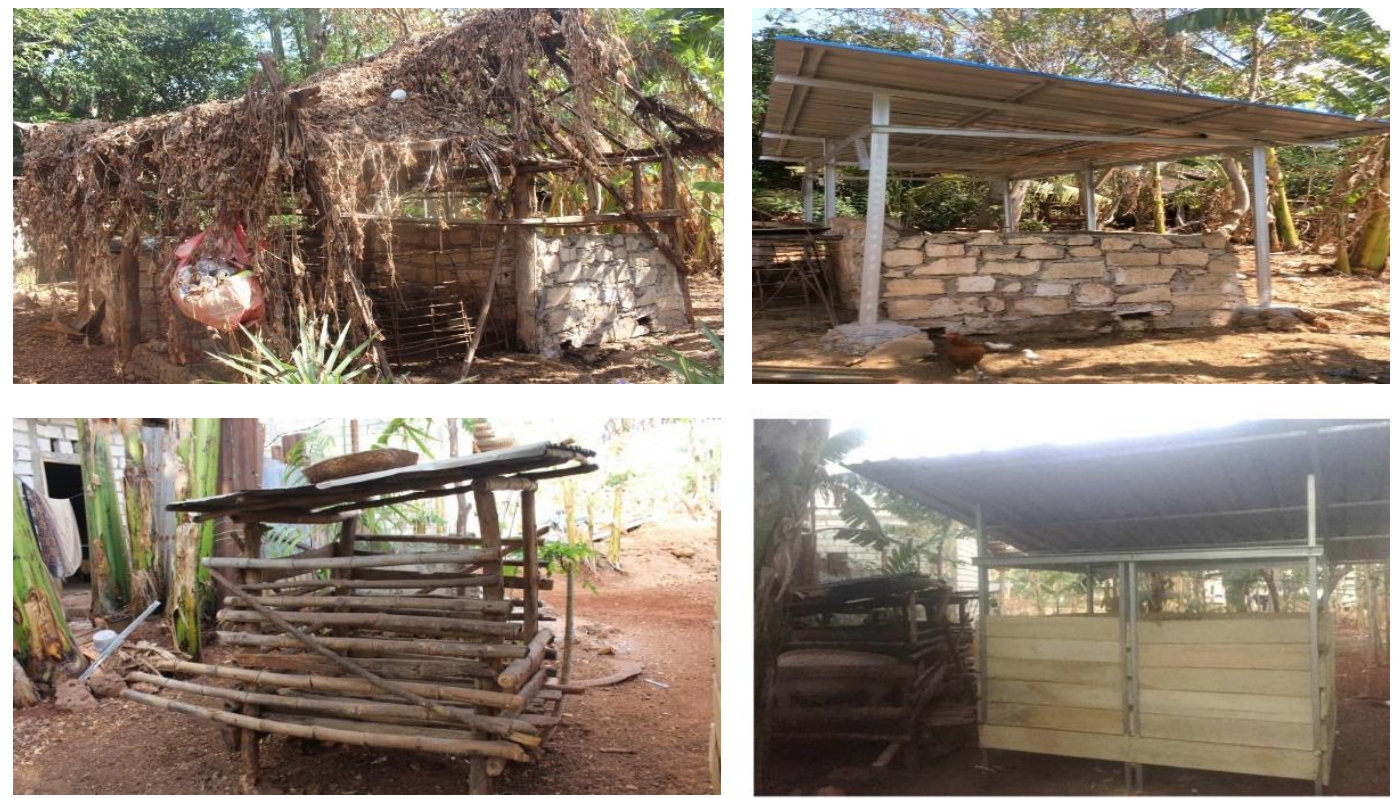


\section{Tahap 4. Pembuatan Pakan Fermentasi Ternak Babi}

Tahapan berikutnya dalam pengabdian ini adalah pembuatan pakan fermentasi untuk ternak babi. Beberapa bahan yang digunakan adalah dedak, batang pisang, batang bira lontar (putak), dan larutan EM4. Keuntungan dari pakan fermentasi ini adalah para peternak dapat menghemat biaya jika mereka membuat pakan ternak dengan mengelola dan menggunakan sumberdaya yang telah tersedia. Pakan fermentasi ini dapat diberikan pada ternak babi dengan tetap memperhatikan pola ransum yang tepat bagi pertumbuhan sesuai fase pemeliharaannya atau dapat diselingi dengan limbah dapur. Dengan pemberian pakan fermentasi ini, diharapkan dapat memanfaatkan potensi limbah yang ada disekitar kita yang bermanfaat bagi peningkatan produktifitas ternak.

Adanya aktivitas fermentasi mikroorganisme tertentu yang bermanfaat dapat meningkatkan tingkat kemudahan dicerna serta masa kadaluwarsa pakan babi.
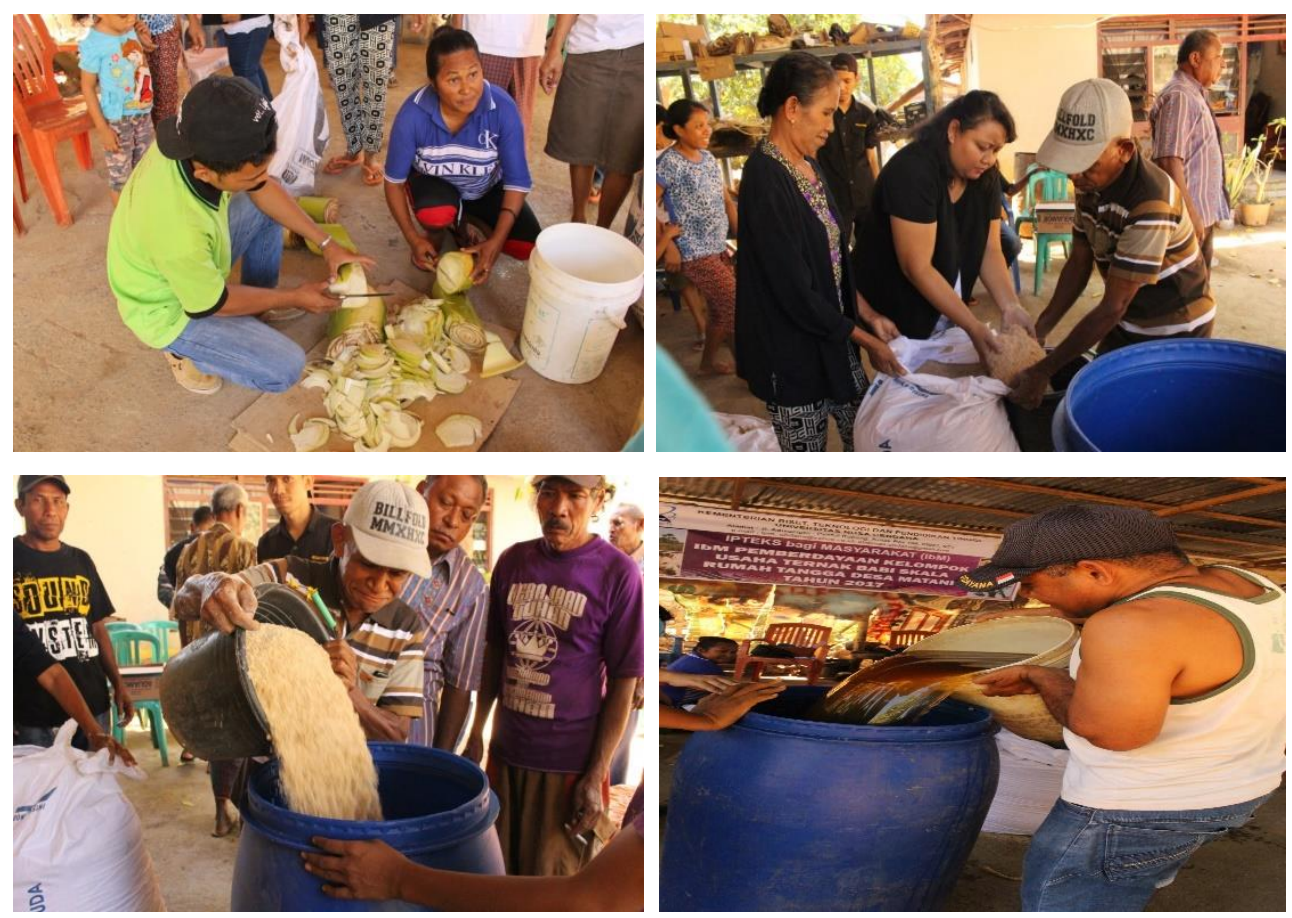


\section{KESIMPULAN DAN SARAN}

\section{Kesimpulan}

Dapat disimpulkan bahwa kegiatan pengabdian berjalan dengan baik dengan terlibatnya masyarakat peternak Matani Helituan dalam mengikuti pelatihan maupun kerjasama dalam berbagai tahapan kegiatan pengabdian yang teramati dari adanya peningkatan pengetahuan dan keterampilan peternak serta perubahan sikap dalam memelihara ternak babi yang berorientasi pada kesehatan dan kesejahteraan ternak babi. Hal ini menjadi sangat penting dalam mendukung peningkatan pertumbuhan dan produktivitas ternak babi skala rumah tangga.

\section{Saran}

Peternak babi skala rumah tangga harus lebih memperhatikan kesehatan lingkungan kandang sehingga kesehatan ternak yang berlandaskan pada aspek kesejahteraan hewan dapat lebih terjamin.

\section{DAFTAR PUSTAKA}

Ariana, I. N. 2011. Pengaruh model lantai kandang dan jenis kelamin terhadap penampilan produksi anak babi lepas sapih. Majalah Ilmiah Peternakan, 14(1).

Aritonang, D. 1993. Babi “perencanaan dan pengelolaan usaha”. PT. Penebar Swadaya, Jakarta

Indonesia, P.R., Undang-Undang Republik Indonesia Nomor 18 Tahun 2009 Tentang Peternakan Dan Kesehatan Hewan.

Korte, S.M., Olivier, B. and Koolhaas, J.M., 2007. A new animal welfare concept based on allostasis. Physiology \& behavior, 92(3), pp.422-428.

Lailogo, O.T., Hau, D.K. and Nulik, J., 2014. Produk ternak dan inovasi teknologi peternakan menunjang keamanan pangan hewani di Nusa Tenggara Timur. JITV, 19(3).

\section{UCAPAN TERIMAKASIH}

Penghargaan yang setingginya diberikan kepada Kementerian Riset, Teknologi dan Pendidikan Tinggi (KEMENRISTEK - DIKTI) yang telah menyetujui dan mendanai pelaksanaan program pengabdian masyarakat (PPM) Tahun Anggaran 2017. 